\title{
The Effect of Education on the Compliance of Nurses Working at Surgical Units to Isolation Measures
}

\section{Cerrahi Birimlerde Çalışan Hemşirelerin Izolasyon Önlemlerine Uyumunda Eğitimin Etkisi}

\author{
(D) Emine KARAGÜLLE KOZA, D Tülin YILDIZ \\ Tekirdağ Namık Kemal University, Institute of Health Sciences, Department of Nursing, Tekirdağ, Turkey
}

ÖZ

\begin{abstract}
Aim: This study has been planned and performed as a descriptive and cross-sectional study to evaluate the adaptation of nurses working in surgical
\end{abstract} departments to the isolation precautions.

Materials and Methods: The target population of the study included 250 nurses working in the surgical departments of University, State and Private hospitals, and the sample of the study included 144 nurses who were volunteer to participate in the study and who met the sampling criteria. The data were obtained through the "Worker's Data Form which was developed in line with the literature and experts' opinion" and "Adaptation Scale To the Isolation Precautions" developed by Tayran (2009), and then these data were evaluated by using appropriate statistical methods within Statistical Package for the Social Sciences 22.00 statistical package programme.

Results: The mean age of the surgical nurses participated in the study was $28.9 \pm 8.49$ years. Of them, $91 \%$ were women, $56.3 \%$ were university graduate, 58.3\% were in profession for less than five years, 81.9\% were in the department for less than five years, 32.6\% worked in state hospital, $36.1 \%$ in university hospital, $31.3 \%$ in private hospitals, $34.7 \%$ in the ward, $27.8 \%$ in operating room, and $37.52 \%$ in intensive care. Immediately after the education, the adaptation score of the nurses to the isolation precautions was calculated as $80.389 \pm 7.106$ over 90 ( $p<0.05$ ).

Conclusion: The adaptation score of the nurses working in surgical departments was higher than that before the education. It has been suggested that the institution should support the adaptation of the nurses to the isolation precautions, education should be planned considering the professional characteristics of the nurses and the factors of the institution, and this training should be repeated with regular intervals.

Keywords: Surgical nurse, education, hospital infection, isolation precautions, adaptation

\section{ABSTRACT}

Amaç: Araştırma, cerrahi birimlerde çalışan hemşirelerin eğitim öncesi (EÖ) ve eğitim sonrası (ES) izolasyon önlemlerine uyumlarını değerlendirmek amacıyla tanımlayıcı ve kesitsel nitelikte planlandı ve uygulandı.

Gereç ve Yöntem: Araştırmanın evrenini; üniversite, devlet ve özel hastanelerin cerrahi kliniklerinde çalışan 250 hemşire, örneklemi ise örneklem seçim kriterlerini karşılayan ve çalışmaya katılmaya gönüllü 144 hemşire oluşturdu. Veriler literatür bilgileri doğrultusunda ve uzman kişilerin görüşleri alınarak araştırmacılar tarafından hazırlanan "Çalışan Veri Formu" ve Tayran tarafından (2009) geliştirilen "İzolasyon Önlemlerine Uyum Ölçeği" ile toplandı. Statistical Package for the Social Sciences 22.00 istatistik paket programında, uygun istatistiksel yöntemler kullanılarak veriler değerlendirildi.

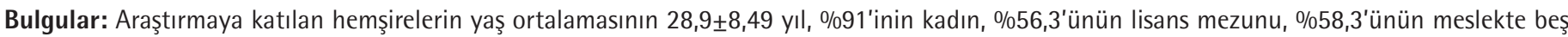
yıldan daha az tecrübesi olduğu, \%81,9'unun ise çalışılan birimde beş yıldan daha az çalışma süresine sahip olduğu, \%32,6'sının devlet \%36,1'inin üniversite, \%31,3'ünün özel hastanelerde çalıştıkları, \%34,7'sinin servis, \%27,8'inin ameliyathane ve \%37,52'sinin yoğun bakım birimlerinde çalıştığı

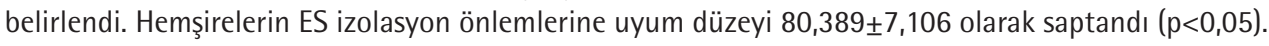

Sonuç: Cerrahi birimde çalışan hemşirelerin izolasyon önlemlerine uyum puanları EÖ'ye göre, ES en yüksek bulunurken, puanın 1. ayda biraz düştüğü 3. ayda ise ES'ye göre daha da düşük olduğu belirlendi. Hemşirelerin izolasyon önlemlerine uyumları konusunda kurumsal desteğin sağlanması, hizmet içi eğitimlerde hemşirelerin mesleki özellikleri ve kurumsal faktörler dikkate alınarak planlamaların yapılması ve eğitimlerin düzenli aralıklarla tekrarlanması önerilmektedir.

Anahtar Kelimeler: Hemşire, hastane enfeksiyonları, izolasyon önlemleri, uyum

Address for Correspondence: Tülin YILDIZ MD, Tekirdağ Namık Kemal Üniversitesi, Sağlık Bilimleri Enstitüsü, Hemşirelik Anabilim Dalı, Tekirdağ, Türkiye Phone: +90 2822503100 E-mail: tyildiz70@hotmail.com ORCID ID: orcid.org/0000-0002-4981-6671

Received: 19.12.2020 Accepted: 18.04.2021 


\section{INTRODUCTION}

Globally, healthcare-associated infections (HCAI) have become a medical problem in healthcare settings. It is estimated that more than 1.4 million people worldwide experience complications due to transmission in hospitals ${ }^{1}$. HCAl is defined as the most important source of mortality and morbidity by the Centers for Disease Control and Prevention and the World Health Organization (WHO) ${ }^{2}$. WHO states that 20\% of HCAl in developed countries and more than $40 \%$ in developing countries are preventable ${ }^{3,4}$. HCAI can cause loss of workforce and productivity, decrease in quality of life/increase in morbidity and mortality, functional disorders, sensory stress, and increase in economic cost due to extra diagnosis and treatment methods, prolonged hospitalization, need for isolation, and increased use of drugs (antibiotics) (3,5-7. $^{3}$.

The most effective way to control HCAl is to isolate the source of infection and patients with infection, and to take isolation precautions. It is extremely important for nurses, who are among health professionals, to know well in which situations isolation is needed, which isolation to apply and which isolation covers what, and to evaluate their attitudes and behaviors towards isolation measures with the right technique and intervals ${ }^{8,9}$. Urinary system infections (42\%) are the most common in HCAI, and followed by surgical site infections (SSI) (40\%). Therefore, surgery has an important place in HCAl. Surgical interventions increase the possibility of encountering endogenous and exogenous microorganisms by disrupting the skin integrity of the individual ${ }^{10}$. These infections are not limited to the intervention site, but may lead to more extensive systemic effects. Healthcare professionals should prioritize and adhere to strict infection prevention and control practices for the safety of patients and themselves. In the studies conducted, it is stated that the members of the Infection Control Committee have difficulties in ensuring and maintaining their adaptation to the isolation measures ${ }^{11,12}$. In this context; the research was carried out to evaluate the adaptation of nurses working in surgical units with isolation precautions before training (BT) and after training (AT).

\section{MATERIALS AND METHODS}

The research is a descriptive cross-sectional study conducted between April and November 2016 with nurses working in the surgical units of university, public and private hospitals in a province. The population of the study consisted of nurses working in the surgical units of hospitals $(n=250)$. Seventysix nurses who were on annual leave, maternity leave, military leave and who were not willing to participate in the study were excluded from the study. The sample included 174 nurses working in the surgical unit. A pilot study was conducted with 30 nurses to check the comprehensibility of the questionnaires and scales, and these nurses were excluded from the study, and the sample consisted of 144 nurses. The data were collected by face-to-face interview method using the "Worker's Data Form" and "Adaptation Scale to the Isolation Precautions" (ISIP) prepared by the researchers in line with the literature and by taking the opinions of experts.

\section{Worker's Data Form}

The data form prepared by the researcher by taking the opinions of experts and in line with the literature information ${ }^{4,13}$ consisted of 17 questions asking about age, gender, educational status, institution, unit of employment, duration of work in the profession, duration of work in the unit, isolation precautions and hospital infections.

\section{Adaptation Scale to the Isolation Precautions}

It was developed by Tayran ${ }^{14}$ in 2009. In order to measure the adaptation of nurses and physicians with isolation measures, the validity and reliability of the scale consisting of a total of 18 positive and negative items was conducted by Tayran and Ulupınar $^{15}$ in 2011. The rating on the scale is 5-point Likert type; $1=\mid$ strongly disagree $2=\mid$ disagree $3=\mid$ have no idea $4=1$ agree $5=1$ strongly agree. Negative statements in the scale are the $5^{\text {th }}, 7^{\text {th }}, 12^{\text {th }}$ and $17^{\text {th }}$ items and are scored as $1=5,2=4,3=3$, $4=2,5=1$. Other positive items are scored from the smallest to the largest $(1,2,3,4,5)$. Adaptation to isolation measures is evaluated by calculating the total score. The total score (lowest score 18, highest score 90) or mean (lowest mean 1; highest mean 5) can be used for scoring. The higher the score, the higher the adaptation. The Cronbach's alpha value of the scale was found to be 0.85 .

The data in the study were collected in four stages.

1. Stage: Testing the data collection form; In order to evaluate the usability of the forms, a questionnaire was applied to a total of 30 nurses, 10 from each institution, who agreed to participate in the study. It was reviewed whether there were any missing/understandable questions. These nurses were not included in the sample of the study.

2. Stage: Nurses who accepted to participate in the study were given training on isolation measures for 30 minutes on days determined by the institutions. Data were collected by faceto-face interview method using the "Worker's Data Form" and ISIP BT and immediately AT.

3. Stage: Data were collected again 1 month after the training (AT1) using the "Worker's Data Form" and ISIP.

4. Stage: Three months after the training (AT3), the data were collected again using the "Worker's Data Form" and ISIP. 


\section{Statistical Analysis}

The findings were analyzed using the Statistical Package for the Social Sciences 22.0 package program. The Student's t-test was used for the comparisons of normally distributed variables between two groups, the Mann-Whitney $U$ test for the comparisons of two groups not showing normal distribution, the One-Way ANOVA test for the comparisons of three or more normally distributed groups, and the Bonferroni test for pairwise comparisons. The Kruskal-Wallis test was used for the comparisons of three or more groups not showing normal distribution and Bonferroni-Dunn test was used for pairwise comparisons.

Qualitative variables were compared using the Pearson chisquare test and Fisher Freeman Halton test. In all analyses, a $p$ value of $<0.05$ was considered statistically significant and the confidence interval was 95\%. Continuous variables were reported as mean \pm standard deviation and categorical variables as percentages and numbers.

\section{RESULTS}

According to the results obtained, it was determined that the mean age of the nurses was $28.29 \pm 8.49$ years, and the majority of them were female, had a bachelor's degree, and worked less than five years both in the profession and in the unit they worked (Table 1). A statistically significant difference was found in the levels of adaptation in the BT evaluation according to the duration of employment in the profession $(p=0.030 ; p<0.05)$. As a result of the pairwise comparisons made to determine the group that caused the significant difference; the level of adaptation of nurses working in the profession for 6-10 years was found to be higher than those working for 11 years or longer $(p=0.025$; $p<0.05)$ (Figure 1, Table 2).

A statistically significant difference was found in the levels of adaptation in the AT3 measurement considering the unit where they worked $(p=0.031 ; p<0.05)$. As a result of the pairwise comparisons made to determine the group that caused the significant difference; the adaptation levels of the nurses working in the intensive care unit were found to be higher than those working in the ward $(p=0.033 ; p<0.05)$ (Table 3$)$.

It was determined that the majority of the participants answered the question about the most important method in preventing nosocomial infection (NI) as handwashing at the

Table 1. Distribution of demographic and occupational characteristics of nurses by institution

\begin{tabular}{|c|c|c|c|c|c|c|}
\hline & & \multicolumn{3}{|l|}{ Institution } & \multirow[b]{2}{*}{$\begin{array}{l}\text { Total } \\
n=144\end{array}$} & \multirow[b]{2}{*}{ p } \\
\hline & & $\begin{array}{l}\text { Public } \\
n=47 \\
(32.6 \%)\end{array}$ & $\begin{array}{l}\text { University } \\
n=52 \\
(36.1 \%)\end{array}$ & $\begin{array}{l}\text { Private } \\
n=45 \\
(31.3 \%)\end{array}$ & & \\
\hline \multirow{5}{*}{ Age (year) } & Min.-max. (median) & $20-58(36)$ & $18-39(25)$ & $18-50(21)$ & $18-58$ & \multirow{2}{*}{${ }^{\mathrm{a}} 0.001^{* *}$} \\
\hline & $\mathrm{M}_{ \pm} \mathrm{SD}$ & $36.04 \pm 8.41$ & $25.65 \pm 3.71$ & $23.24 \pm 6.77$ & $28.9 \pm 8.49$ & \\
\hline & $18-28$ years & $7(14.9)$ & $38(73.1)$ & $40(88.9)$ & & \\
\hline & $29-38$ years & $24(51.1)$ & $13(25.0)$ & $2(4.4)$ & & \\
\hline & $\geq 39$ years & $16(34.0)$ & $1(1.9)$ & $3(6.7)$ & & \\
\hline \multirow{2}{*}{ Gender } & Female & $44(93.6)$ & $44(84.6)$ & $43(95.6)$ & $131(91)$ & \multirow{2}{*}{${ }^{\mathrm{b}} 0.161$} \\
\hline & Male & $3(6.4)$ & $8(15.4)$ & $2(4.4)$ & $13(9)$ & \\
\hline \multirow{4}{*}{ Educational status } & High school & $1(2.1)$ & $6(11.6)$ & $34(75.6)$ & $41(28.5)$ & \multirow{3}{*}{${ }^{\mathrm{b}} 0.001^{*}$} \\
\hline & Associate degree & $14(29.8)$ & $1(1.9)$ & $0(0)$ & $15(10.4)$ & \\
\hline & Undergraduate degree & $30(63.8)$ & $41(78.8)$ & $10(22.2)$ & $81(56.3)$ & \\
\hline & Graduate degree & $2(4.3)$ & $4(7.7)$ & $1(2.2)$ & $7(4.9)$ & \\
\hline \multirow{3}{*}{$\begin{array}{l}\text { Time of working in } \\
\text { the profession }\end{array}$} & $0-5$ years & $8(17.0)$ & $36(69.2)$ & $39(86.7)$ & $84(58.3)$ & \multirow{3}{*}{${ }^{\mathrm{c}} 0.001^{* *}$} \\
\hline & $6-10$ years & $13(27.7)$ & $15(28.8)$ & $4(8.9)$ & $32(22.2)$ & \\
\hline & $\geq 11$ years & $26(55.3)$ & $1(1.9)$ & $1(4.4)$ & $28(19.5)$ & \\
\hline \multirow{3}{*}{ Unit of working } & Service & $17(36.2)$ & $14(26.9)$ & $19(42.2)$ & $50(34.7)$ & \multirow{3}{*}{${ }^{c} 0.497$} \\
\hline & Operating room & $11(23.4)$ & $18(34.6)$ & $11(24.4)$ & $40(27.8)$ & \\
\hline & Intensive care & $19(40.4)$ & $20(38.5)$ & $15(33.3)$ & $54(37.5)$ & \\
\hline \multirow{3}{*}{$\begin{array}{l}\text { Time of working in } \\
\text { the unit }\end{array}$} & $0-5$ years & $26(55.3)$ & 51 (98.1) & 41 (91.1) & 118 (81.9) & \multirow{3}{*}{${ }^{\mathrm{b}} 0.001^{* *}$} \\
\hline & $6-10$ years & $11(23.4)$ & $1(1.9)$ & $3(6.7)$ & $15(10.4)$ & \\
\hline & $\geq 11$ years & $10(21.3)$ & $0(0)$ & $1(2.2)$ & $11(7.7)$ & \\
\hline
\end{tabular}


highest rate before, during, one month after, and 3 months after the training (Table 4).

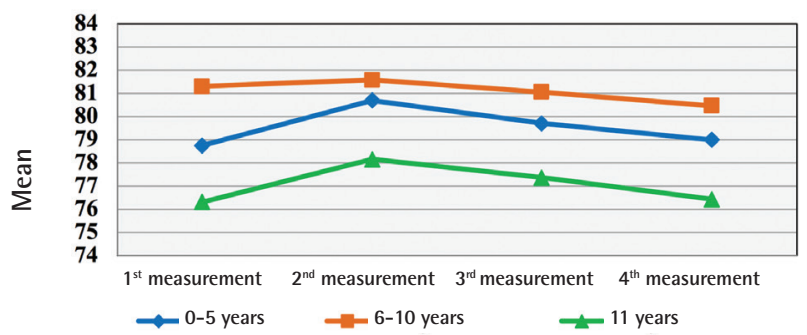

Figure 1. Correlation graph showing the adaptation levels of nurses to isolation precautions by working time in the profession
Compared to pre-training, the level of adaptation to isolation measures was found to be highest right after the training, and it was determined that it decreased 1 month and 3 months after the training (Figure 2).

\section{DISCUSSION}

When it is considered that HCAI is preventable and SSIs are in the second place after urinary system infections in HCAl, the roles and responsibilities of surgical nurses in the control and prevention of HCAI and SSIs are even more important. In the study, it was determined that the average age of the nurses and their working time in the profession were effective in their adaptation to isolation measures $(p<0.05)$. In a study on nurses with a mean age of $30.11 \pm 6.34$ years, which was conducted by

Table 2. Distribution of nurses' adaptation scores to isolation measures by age range

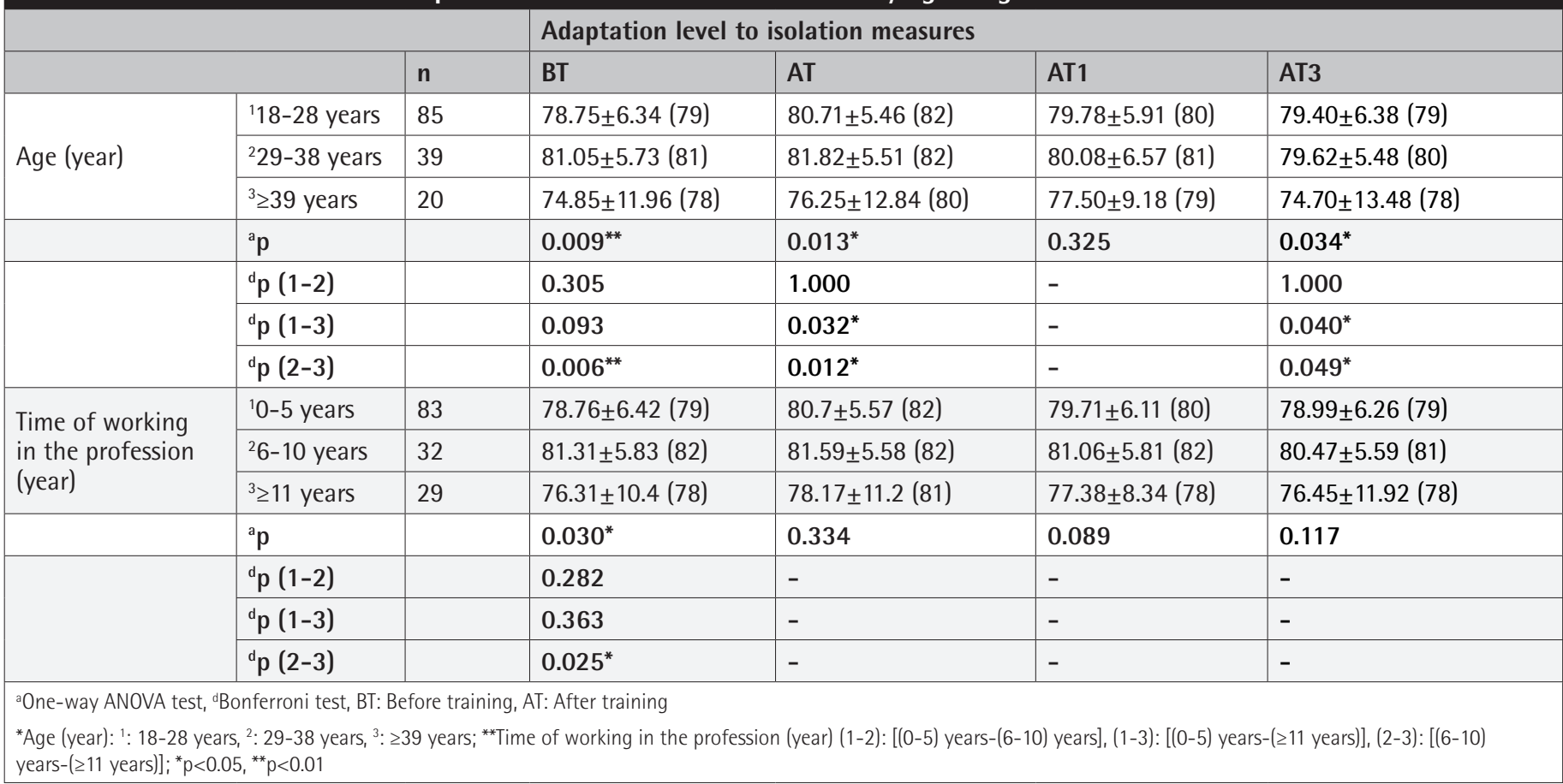

Table 3. Distribution of nurses' adaptation scores to isolation measures by unit of working

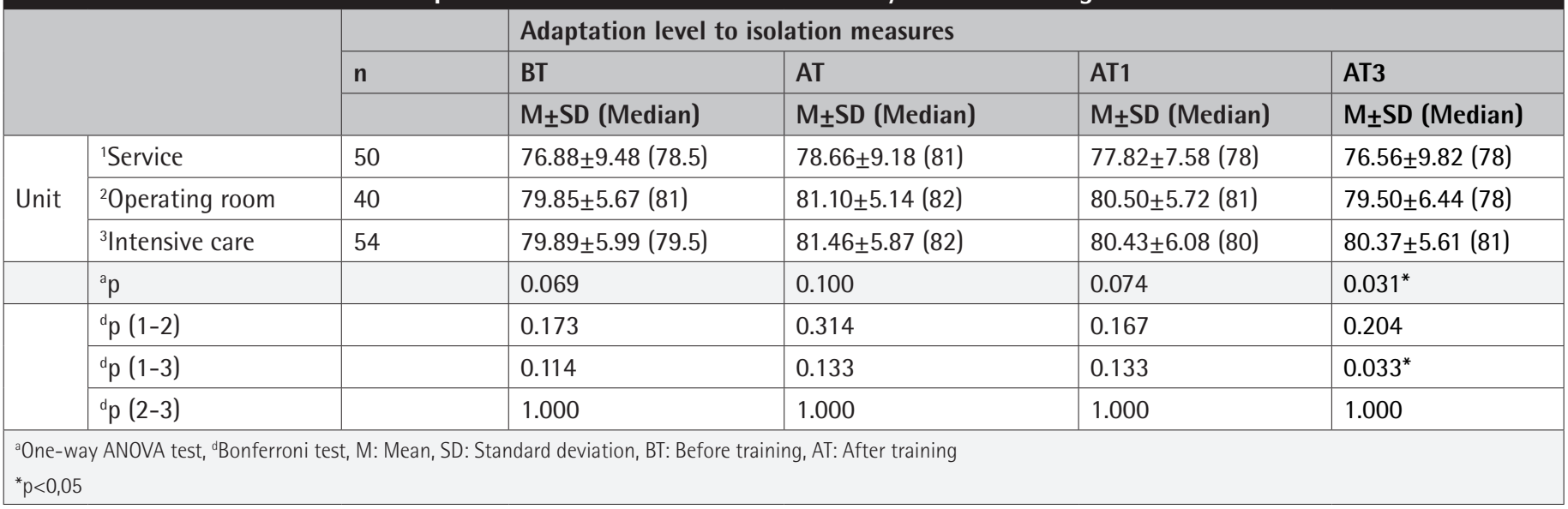


Table 4. Evaluation of nurses' definitions given to the question about the most important method in preventing nosocomial infection

\begin{tabular}{|c|c|c|c|c|c|}
\hline \multirow{2}{*}{\multicolumn{2}{|c|}{ n (\%) }} & BT & AT & AT1 & AT3 \\
\hline & & n (\%) & n (\%) & n (\%) & \\
\hline \multirow{4}{*}{$\begin{array}{l}\text { What is the most } \\
\text { important method in } \\
\text { preventing NI? }\end{array}$} & Wearing gloves & $39(27.1)$ & $9(6.3)$ & 17 (11.8) & 22 (15.3) \\
\hline & UV use & $0(0)$ & $1(0.7)$ & $0(0)$ & $1(0.7)$ \\
\hline & Isolation & $28(19.4)$ & $17(11.8)$ & $32(22.2)$ & 27 (18.8) \\
\hline & Hand washing & 77 (53.5) & $117(81.3)$ & $95(66.0)$ & $94(65.3)$ \\
\hline
\end{tabular}

Adaptation level to isolation measures

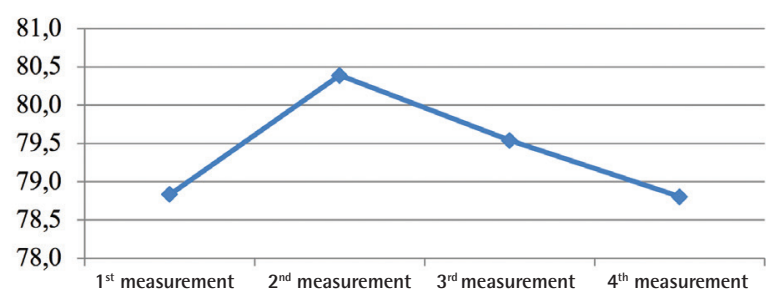

Figure 2. Correlation graph showing nurses' adaptation scores to isolation precautions

$1^{\text {st }}$ measurement: before training, $2^{\text {nd }}$ measurement: immediately after training, $3^{\text {rd }}$ measurement: 1 month after training, $4^{\text {th }}$ measurement: 3 months after trainin

Zencir et al. ${ }^{16}$, it was determined that factors such as age and working time in the profession affect adaptation to isolation measures. On the other hand, Yüceer et al. ${ }^{17}$ found that age and working time increased adaptation to isolation measures. Erden et al. ${ }^{18}$ evaluated the adaptation of doctors and nurses working in intensive care units to isolation measures, and found that the mean age did not affect adaptation to isolation measures, but the working time in the unit increased adaptation to isolation measures. In line with these results; except for the mean age in the study of Erden et al. ${ }^{18}$, the studies are similar to the results of our research.

Considering that most of the NIs seen in intensive care units can result in death, adaptation to isolation measures is of great importance in the prevention of these infections. In the study, a statistically significant difference was found between the levels of adaptation in the AT3 measurement according to the unit they worked $(p=0.031 ; p<0.05)$. In Özden and Özveren's ${ }^{3}$ study on the determination of occupational and institutional factors in nurses' adaptation to isolation measures, the adaptation scores of nurses working in intensive care to isolation measures $(68.60 \pm 10.68)$, was found to be higher than the nurses working in internal $(65.57 \pm 13.25)$ and surgical $(66.86 \pm 10.79)$ units. In our study, the adaptation levels of the nurses working in the intensive care unit were similarly higher than those working in the service $(p=0.033 ; p<0.05)$.
According to the findings obtained in the study, it was determined that the most effective method was hand washing according to the answers given to the question "What is the most important method in preventing HCAI?" The results suggested that the trainings on handwashing, observations and the continuity of trainings were effective in all units.

\section{Study Limitations}

Since the research is limited to the nurses working in the surgical units of university, public and private hospitals, it cannot be generalized to all surgical nurses. The evaluation of the adaptation of nurses working in surgical units to isolation precautions BT and AT is limited to the items in the ISIP and the questions in the Worker's Data Form.

\section{CONCLUSION}

According to the findings obtained, it was determined that the adaptation of the nurses working in the surgical units of the hospitals to the isolation measures increased immediately after the training, 1 month and 3 months after the training compared to the pre-training, but the highest increase occurred immediately after the training. It was determined that the longer the time passed after the training, the lower the adaptation scores. It is thought that regular and repetitive in-service trainings affect adaptation to isolation measures, and demographic and occupational characteristics are also effective in adaptation to isolation measures.

\section{Ethics}

Ethics Committee Approval: The study were approved by the Tekirdağ Namık Kemal University of Ethics Committee (protocol number: 2016/62/04/11, date: 14/04/2019).

Informed Consent: Consent form was filled out by all participants.

Peer-review: Externally peer-reviewed.

\section{Authorship Contributions}

Concept: T.Y., Design: E.K.K., T.Y., Data Collection or Processing: E.K.K., T.Y., Analysis or Interpretation: E.K.K., T.Y., Literature Search: E.K.K., T.Y., Writing: T.Y. 
Conflict of Interest: No conflict of interest was declared by the authors.

Financial Disclosure: The authors declared that this study received no financial support.

\section{References}

1. Suliman M, Aloush S, Aljezawi M, AlBashtawy M. Knowledge and practices of isolation precautions among nurses in Jordan. Am J Infect Control. 2018;46:680-4.

2. Mankan T, Kaşıkçı MK. Hemşirelerin Hastane Enfeksiyonlarının Önlemeye İlişkin Bilgi Düzeyleri. İnönü Üniversitesi Sağlık Bilimleri Dergisi. 2015;4:116.

3. Özden D, Özveren H. Hemşirelerin İzolasyon Önlemlerine Uyumunda Mesleki ve Kurumsal Faktörlerin Belirlenmesi. JAREN Hemşirelik Akademik Araştırma Dergisi. 2016;2:24-32.

4. Tanyeri K. Hemşirelerin Hastane Enfeksiyonlarını Önlemede İzolasyon Önlemlerine Uyumlarının Belirlenmesi. Sağlık Bilimleri Enstitüsü, Yüksek Lisans Tezi. KKTC Yakın Doğu Üniversitesi. 2018.

5. Güleç Şatır D, Er Güneri S, Öztürk R, Bülbül Maraş G, Mertoğlu A, Sevil Ü. Hemşirelerin izolasyon önlemlerine uyumları ve etkileyen faktörlerin değerlendirilmesi: İzmir örneği. Tepecik Eğit ve Araşt Hast Dergisi. 2019;29:218-22

6. Bülüç F, Ağırbaş İ. Hastanelerde Maliyet Analizi: Kamu Hastanesi Örneği. SGD-Sosyal Güvenlik Dergisi. 2017;7:181-210.

7. Şahin AR, Yıldız BT, Aktemur A, Topal B, Nazik $S$, Ateş S. Bir üniversite hastanesi noroloji yoğun bakım ünitesinde gelişen enfeksiyonların değerlendirilmesi. Çağdaş Tıp Dergisi. 2019;9:43-7.

8. Şahin H, Akıncı G. İzolasyon Yöntemleri. Hastane İnfeksiyonları Kontrolü El Kitabı. Türkyılmaz R. (Ed.). Hastane Infeksiyonları Derneği Yayını No: 2 , Bilimsel Tıp Yayınevi, Ankara. 2004:309-16.
9. Abdulrahem IS, Amodu M, Saka M, Bolarinwa OA, Uthman MMB. Knowledge, Awareness and Compliance with Standard Precautions among Health Workers in North Eastearn Nigeria. J Community Med Health Edu. 2012;2:1-5.

10. Ok E. Cerrahi Alan Enfeksiyonları. Doğanay M, Ünal S, Çetinkaya Şardan Y (ed). Hastane Enfeksiyonları. 2013;899-914.

11. Alp E. Enfeksiyon Kontrol Programı. 55. Baskı, Kayseri: Erciyes Üniversitesi Rektörlük Matbaası. 2012;43-51.

12. Öncül A, Koçulu S, Elevli K. Bir Devlet Hastanesinin Yoğun Bakım Ünitelerinde Kazanılan Hastane Enfeksiyonlarının Epidemiyolojisi, Şişli Etfal Hastanesi Tıp Bülteni. 2012;46:60-6.

13. Demir Z. Çocuklarla Çalışan Hemşire ve Hekimlerin İzolasyon Önlemlerine Uyumunun Değerlendirilmesi. Sağlık Bilimleri Enstitüsü, Hemşirelik Anabilim Dalı. Yüksek Lisans Tezi. Mersin 2014.

14. Tayran N. Hemşire ve Hekimlerin İzolasyon Önlemlerine Uyumu. Marmara Üniversitesi Sağlık Bilimleri Enstitüsü. Yüksek Lisans Tezi. İstanbul 2010.

15. Tayran N, Ulupınar S. Bir Ölçek Geliştirme Çalışması: İzolasyon Önlemlerine Uyum Ölçeğinin Geçerlik ve Güvenirliği. Florance Nightingale Hemşirelik Dergisi. 2011;19:89-98.

16. Zencir G, Bayraktar D, Khorshid L. Bir Kamu Hastanesi'nde Çalışan Hemşirelerin İzolasyon Önlemlerine Uyumu. Ege Üniversitesi Hemşirelik Fakültesi Dergisi. 2013;29:61-70.

17. Yüceer $S$, Bulut $H$, Öztürk F. Nöroşirürji Yoğun Bakım Ünitesinde Çalışan Hemşirelerin ve Doktorların İzolasyon Önlemlerine Uyumlarının Değerlendirilmesi. Türk Nöroşirurji Dergisi. 2012;22:341-2.

18. Erden S, Bayrak Kahraman B, Bulut H. Yoğun Bakım Ünitelerinde Çalışan Doktor ve Hemşirelerin İzolasyon Önlemlerine Uyumlarının Değerlendirilmesi. 2015;4:388-98. 